\title{
Line of Social Transformation: Collinearity Research - Innovation - Technology Transfer
}

\author{
Manuel Emilio Milla Pino ${ }^{1 *}$, Danny Alberto Villegas Rivas ${ }^{1}$, María Marleni Torres $\mathrm{Cruz}^{2}$ and \\ Witre Omar Padilla ${ }^{3}$ \\ ${ }^{1}$ Faculty of Civil Engineering, National University of Jaen, Cajamarca, Peru \\ ${ }^{2}$ Faculty of Forestry and Environmental Engineering, National University of Jaen, Cajamarca, Peru \\ ${ }^{3}$ Faculty of Health Sciences, National University Toribio Rodriguez de Mendoza, Amazonas, Peru
}

*Corresponding author: Manuel Emilio Milla Pino, Faculty of Civil Engineering, National University of Jaen, Cajamarca, Peru

\begin{tabular}{|c|c|}
\hline ARTICLE INFO & ABSTRACT \\
\hline Received: 猘 May 04, 2021 & $\begin{array}{l}\text { In this scientific note, a contextualization of research, innovation and technology } \\
\text { transfer is presented. in order to demonstrate the need that society has for the actions }\end{array}$ \\
\hline Published: 幽 May 11, 2021 & $\begin{array}{l}\text { inherent to these concepts to converge harmoniously, for this it is proposed from an } \\
\text { analogy from mathematics, specifically geometry the conception of a line of social }\end{array}$ \\
\hline
\end{tabular}

Alberto Villegas Rivas, María Marleni Torres Cruz, Witre Omar Padilla. Line of Social Transformation: Collinearity Research - Innovation - Technology Transfer. Biomed J Sci \& Tech Res 35(4)-2021. BJSTR. MS.ID.005744.

\section{Mini Review}

In a geometric context, we can point out that in a triangle, the intersection of the bisectors is the incenter, the intersection of the medians is the barycenter, the intersection of the bisectors is the circumcenter and the intersection of the heights is the orthocenter, points that reflect that it is possible to match elements generated from the vertices and sides of a triangle. Furthermore, if specifically, the triangle does not have all its sides equal, that is, it is nonequilateral, the orthocenter, barycenter and circumcenter are collinear, and they conjugate in what is called the Euler, Borbonet, et al. [1]. In this sense, it is appropriate to imagine that the vertices of a triangle are, research, innovation and technology transfer, respectively, and ask, is it possible to generate lines from research, innovation and technology transfer that coincide at one point? Is it possible that the various coincidence points that are generated are collinear? The foregoing allows us to point out that the fundamental objective of this scientific note is to contextualize, analyze and discuss the need that society has for research, innovation and technology transfer to have at least one point of intersection, which allows the scientific knowledge generated from the investigations carried out in the different spheres of knowledge, they become a vital input for the improvement of the quality of life.

\section{Research}

\section{Idea}

If we assume that the idea constitutes the initial approach to the reality to be investigated, the exhaustive route to find and formulate an alternative solution to an identified problem will be the investigation itself. This means that problems in which one has the conviction to understand them in their proper dimension and possess the necessary training to achieve findings with sufficient quality and impact in the area of knowledge where it is inscribed must be addressed. In this sense, we can limit that Einstein expressed "we devise one theory after another and we do it because we enjoy understanding", making it clear that the results of one investigation inspire the realization of another. Likewise, Aristotle stated that "understanding is one of the greatest pleasures for 
man, even if he believes that he does not have the capacity to do it", emphasizing that we all have the talent required to generate novel results from investigative processes.

\section{Contributions}

It is essential that all researchers establish as premises that their work should contribute to two directions, strengthen the methodological heritage and improve the work of science through scientific knowledge, which can be verified in the light of uncertainty, managing to enhance the sphere of knowledge [2].

\section{Innovation}

\section{Creativity}

Innovation is a process that incorporates new features and refers to the modification of elements in order to improve them, although the possibility of implementing totally new elements is not denied. This indicates that creation is the concept and innovation is the process [3].

\section{Quality Control, Assurance and Management}

The control is oriented towards the design of activities that allow assessing the quality of the product, which constitutes a reactive function, since, if the product does not conform to the specifications, it will be rejected. The assurance is synonymous with a set of planned and systematic activities that an organization develops, with the purpose of granting the confidence that the product satisfies the quality conditions. The management is in charge of directing and controlling organizational activities for the establishment of quality policies that guarantee planning, control, assurance and continuous quality improvement. Hence, control is focused on assessing quality, assurance provides confidence that the product meets the requirements and management effectively and efficiently sets the quality policy.

\section{Technology Transfer}

\section{Development and Growth}

We must take on the challenge of promoting the development and growth of the various sectors of society through access to the

\section{ISSN: 2574-1241}

DOI: $10.26717 /$ BJSTR.2021.35.005744

Manuel Emilio Milla Pino. Biomed J Sci \& Tech Res

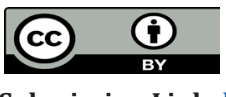

This work is licensed under Creative Commons Attribution 4.0 License

Submission Link: https://biomedres.us/submit-manuscript.php knowledge and experience of research, innovation and development groups.

\section{Technological Empowerment}

The transfer has the following scopes, generates value and competitiveness, promotes continuous development, makes knowledge represent new opportunities, stimulates research and development, guarantees space for innovation and strengthens production, creating possibilities to consolidate intellectual property.

\section{Link between Research, Innovation and Technology Transfer}

The project is the formal expression of the conception of the research, in which the results obtained constitute the findings that are expected to be loaded with particular novelty. These findings must be progressively evaluated and reveal their innovative nature, an aspect that will open the window that will lead us to the establishment of a patent within the world of intellectual property. The implementation of this patent will guide towards the true development that will consolidate it over time, thus contributing to the improvement of the quality of life of society.

\section{Conclusion}

What is stated in this scientific note, it is only possible to achieve it through the joint action of research, innovation and technology transfer, which, making a mathematical analogy, could be called "Line of Social Transformation", in which this trio would be collinear of vital concepts, thus guaranteeing their operative coexistence in favor of improving the quality of life of society.

\section{References}

1. Borbonet M, Burgos B, Martínez AY, Ravaioli N (2007) Matemática2, Grupo Botadá. In: Borbonet M, Burgos B, Martínez AY, Ravaioli N (Eds.)., Fin de Siglo, Montevideo, Uruguay.

2. Einstein A (1950) On the generalized theory of gravitation. In: Einstein $A$ (Edt.)., Scientific American 182(4): 13-17.

3. Milla M, Villegas D (2017) La metodología de la investigación en el marco de la agroproducción sustentable. Revista de Investigación en Agroproducción Sustentable 1(3): 68-71.

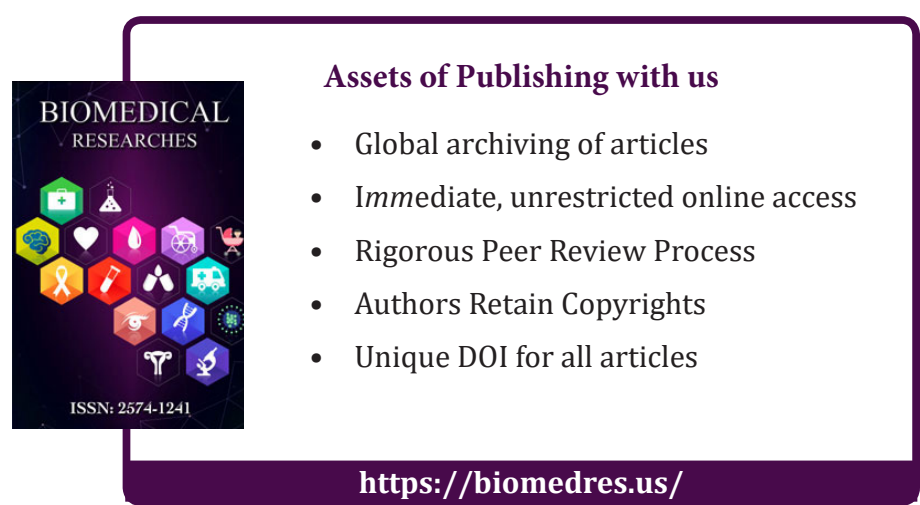

Copyright@ Manuel Emilio Milla Pino | Biomed J Sci \& Tech Res | BJSTR. MS.ID.005744. 